УДК: 35.36 .396

DOI: https://doi.org/10.32689/2618-0065-2020-1(3)-213-222

Черняхівська Вікторія Валеріївна, кандидат наук 3 державного управління доцент кафедри публічного адміністрування, Міжрегіональна Академія управління персоналом, 03039, м. Київ, вул. Фрометівська, 2, тел.: (044) 264-52-54, e-mail: vikysiya@ukr.net.

ORCID: 0000-0003-4135-7770

\title{
ЕВОЛЮЦІЯ ГЕНДЕРНИХ СТЕРЕОТИПІВ ВІДПОВІДНО ДО ТИПІВ ДЕРЖАВИ, ВІДНОСИН ВЛАДИ, ДОМІНУВАННЯ
}

Анотація: Простежено шляхи вдосконалення гендерних стереотипів в системі державного управління відповідно типів держави, відносин влади домінування тощо. В ході дослідження гендерних стереотипів, відносин статей на державній службі та в суспільстві загалом, простежили наступну динаміку. Проаналізувавши наукову літературу виявилось, що в порівняльних характеристиках різних моделей політики гендерної рівності традиційно враховують переважно існуючі моделі типів держав, відносин влади та домінування. Відповідно, поставлено за мету дослідити аналіз типів суспільств, а саме: антропоцентристського і соціоцентристського в рамках соціокультурного підходу.

Аналізуючи літературу дійдено висновку, що в порівняльних характеристиках різних моделей політики гендерної рівності традиційно враховують переважно існуючі моделі типів держав, відносин влади та домінування. Відповідно, що до цього слід додати аналіз типів суспільств: антропоцентристського і соціоцентристського в рамках соціокультурного підходу.

В основу покладено аналіз практичного вирішення питань гендерного дисбалансу в системі державного управління, державної служби та публічного адміністрування 3 точки зору антропоцентричної парадигми наукового пізнання. Тому як, в системі державного управління з точки зору гендерної рівності та викорінення гендерних стереотипів має лежати ідея людиноцентризму як антропологічна основа управління. ÏÏ застосування сприяє тому, щоб правові, політичні, соціальні, економічні інститути були зорієнтовані на індивіда. Тому, що людина, індивід не залежно від статі $є$ осередком управління всіма суспільними процесами. Саме тому, вивчення та втілення ідеї людиноцентризму має лежати в основі усіх суспільнополітичних, державних, економічних, соціальних тощо, суспільних відносин. 
Ключові слова: гендер, гендерна політика, державне управління, суспільство, держава, паритетна демократія, дискримінація, права людини, гендерна рівність.

Chernyakhivska Viktoriya Valeriyivna, Candidate of Sciences in the Public Administration, Associate Professor of the Department of Public Administration, Interregional Academy of Personnel Management, 03039, Kyiv, 2 Frometivska St., tel.: (044) 264-52-54, e-mail: vikysiya@ukr.net.

ORCID: 0000-0003-4135-7770

\section{EVOLUTION OF THE GENDER STEREOTYPES ACCORDING TO THE TYPES OF THE STATE, RELATIONS OF POWER, DOMINATION}

Abstract: The ways of improving gender stereotypes in the public administration system according to the types of the state, relations of power, domination and more are traced. In the course of the study of gender stereotypes, relations of the sexes in the public service and in the society in general, the following dynamics were observed. Analyzing the scientific literature, it has emerged that the comparative characteristics of different models of gender equality policy traditionally take into account predominantly the existing models of the state types, power relations and domination. Accordingly, the aim is to investigate the analysis of the types of societies, namely: anthropocentric and sociocentric within the framework of the socio-cultural approach.

Analyzing the literature, it is concluded that the comparative characteristics of different models of gender equality policy traditionally take into account predominantly the existing models of the state types, power relations and domination. Accordingly, an analysis of the types of the societies: anthropocentric and sociocentric within the sociocultural approach, should be added to this.

The analysis is based on the practical solution of the gender imbalances in the system of the state administration, public service and public management in terms of the anthropocentric paradigm of the scientific knowledge. Because, in the system of the public administration, from the point of view of gender equality and eradication of the gender stereotypes, the idea of humancentrism as an anthropological basis of governance should lie. Its application helps to make the legal, political, social, economic institutions oriented towards the individual. Because a person, an individual, regardless of gender, is the focal point of managing all the social processes. That is why the study and implementation of the idea of human-centrism must underlie all the socio-political, state, economic, social, etc. social relations.

Keywords: gender, gender policy, public administration, society, state, parity democracy, discrimination, human rights, gender equality. 
Постанова проблеми. Діалектика синхронії і діахронії дає можливість пояснити динаміку зміни гендерних стереотипів із збереженням їх фундаментальних характеристик, притаманних конкретному суспільству. Йдеться про принцип який дозволяє пояснити гендерні стереотипи, характерні для конкретного соціокультурного простору, що передбачає виявлення особливостей їх природи 3 урахуванням національно-етнічної специфіки. Також цей принцип передбачає виявлення комплексу причин формування та акумуляції стереотипів 3 позицій їх вертикального історичного розвитку і соціокультурної детермінації, що визначають вектор суспільних трансформацій.

Аналіз останніх досягнень. Питаннями гендерної рівності, гендерними стереотипами займаються ряд науковців як вітчизняних так $\mathrm{i}$ зарубіжних. Таких як, Ш. Берн, В. Брайсон, В. Близнюк, Т. Василевська, Л. Виноградова, О. Войтенко, Л. Воронько, Н. Грицяк, О. Дашковська, I. Дорожкіна, А. Заєць, Ю. Захарова, Е. Здравомислова, В. Кириченко, Л. Кобилянська, А. Колодій, О. Кулачек, М. Кіммел, О. Кісь, В. Кравець, Т. де Лореті, К. Левченко, Т. Мельник, Т. Марценюк, О. Мірошниченко, А. Мищенко, В. Мюллер, О. Новак-Каляєва, Дж. Міль, С. Олійник, Н. Оніщенко, Н. Пархоменко, С. Поленіна, М. Пірен, В. Толстокорова, Н. Чухим тощо, також розглядаються окремі питання прав людини та проблеми впровадження гендерної рівності у суспільних відносинах та в державному управлінні.

Аналізуючи літературу можна дійти висновку, що в порівняльних характеристиках різних моделей політики гендерної рівності традиційно враховують переважно існуючі моделі типів держав, відносин влади та домінування. Відповідно, що до цього слід додати аналіз типів суспільств: антропоцентристського i соціоцентристського в рамках соціокультурного підходу. І ось чому.

Саме метою статті $є$ дослідити аналіз типів суспільств який дасть змогу зрозуміти не тільки соціальні причини (ними можуть бути політичні, економічні, правові,ідеологічні, у тому числі релігійні явища і процеси) усталених у тому чи іншому суспільстві гендерних стереотипів, а й генетично запрограмовані стереотипи на рівні ментальних уявлень про роль чоловіка і жінки в публічній сфері життєдіяльності. Це в комплексі дає змогу пояснити часто існуючі розбіжності між теорією, доктриною, законодавчою практикою і реальними процесами, що відбуваються в суспільстві у частині вирішення проблеми гендерного паритету в системі державного управління.

Виклад основоного матеріалу. Зазначимо, 3 посиланням на нову філософську енциклопедію $[1-14 ; 10]$, що в концепціях антропоцентристського спрямування підкреслюється самостійність індивіда як суб'єкта вільного вибору і відповідального вчинку. В політиці антропоцентризм реалізовано в лібералізмі, який визнає пріоритет інтересів особи перед інтересами будь-яких спільнот і невідчужуваність іiї природних прав. Методологічно антропоцентризм протиставляється натуралістичному 
детермінізму та історизму й означає пріоритет цілепокладальної діяльності людей перед соціальними структурами і так званими марксистськими законами історичної необхідності. Антропоцентричним моделям не притаманне великомасштабне соціальне проектування та жорсткі соціальні технології, які підпорядковують інтереси особистості жорсткій логіці проекту і перетворюють її у «гвинтик» державної машини. Антропоцентризм утілює вимоги щодо співмірності соціальних перетворень та окреслює межі втручання держави в людську повсякденність.

Філософія наголошує, що в антропоцентризмі сутність людини - в іiі унікальності, неповторності, феноменальності, самоцінності. Головним принципом взаємодії людини із собою та навколишнім світом $є:$ а) творча діяльність по створенню своєї самості згідно із суб’єктивними відчуттями; б) вільне, творче, відповідальне перетворення навколишнього середовища (або згідно із суб'єктивними поглядами на світ, або у співтворчості із Творцем) [10]. Ю. Сурмін, з посиланням на відповідне джерело, зазначає [11, с.13], що «суспільствознавство гуманітарне тією мірою, якою передбачає облік суб'єктивного фактора - розгляд людини як особистості, носія індивідуального» [12, с. 125].

В концепціях соціоцентричного спрямування проголошується домінування спільних, колективних інтересів над індивідуальними. Соціоцентристські моделі суспільства із покоління в покоління формувалися общиною, патріархальною сім'єю, патерналістським сприйняттям держави. Ідеологія, що формується цими інститутами, проголошує беззаперечний пріоритет спільного перед приватним, перед індивідуальним. Будь-яка сфера життєдіяльності людини, включаючи національну, духовну, економічну, політичну, управлінську, регулюється цією ідеологією та у будь-який спосіб і у будь-який час набуває відповідного вираження. Пригнічення індивідуального колективним - універсальний стандарт, який пронизує усі сфери суспільного життя. Так, 3 позиції соціоцентризму проблема прав особи, включаючи ii природні права на життя, свободу та незалежність, нівелюється автоматично, оскільки, з точки зору соціоцентризму, названих прав не існує в природі, їх людині надає суспільство (держава). «Суспільна природа», «суспільна сутність» людини проголошуються в контексті доведеного до абсурду колективізму. Особистість в такій системі координат розглядається не як ціль у собі і самостійна цінність для суспільства, а винятково в якості засобу для досягнення ефемерних надособистісних, а тому й абстрактних цілей та результатів.

Таким чином, характеристика антропоцентристського i соціоцентристського типів суспільств дає можливість вивчати витоки (причини) будь-яких суспільних суперечностей (антагоністичних, неантагоністичних, антагональних, агональних) у зрізі об'єктивних і суб'єктивних причин. Об'єктивні причини укорінені в самій соціальній дійсності, у змісті сформованих у суспільстві економічних, політичних, 
культурних та інших відносин, в діяльності різних соціальних інститутів, органів державної влади тощо. Суб’єктивні причини прямо чи опосередковано пов'язані із світським чи релігійним світоглядом окремих соціальних спільнот, системою ціннісних орієнтацій, якими керуються актори, 3 їх глибинними психологічними настановами, що знаходять вираження у відповідних соціальних стереотипах.

Гендерний підхід дозволяє розглянути соціальні стереотипи крізь призму особливостей поведінки індивіда в залежності від статі та уявлень про фемінність та маскулінність у межах культури окремого суспільства. Відповідно стереотипи інтегровані пояснюючими моделями гендерних відносин патріархатної та феміністської, які сформувалися в рамках парадигми «влада-домінування-покора». В цій тріаді влада виступає основним виміром стратифікаційно-статусного поділу, розподіляючи індивідів за соціальними ролями та позиціями. Водночас, згідно з так званою капілярною теорією влади М. Фуко, влада здійснюється не лише через пряме насилля чи домінування, але також через ідентичність та дискурс [13].

Як видається, позиція М. Фуко найбільше кореспондується 3 партнерською моделлю гендерних відносин. Партнерська модель - це стосунки двох рівноправних суб'єктів, кожний з яких має власну цінність, i при наявності індивідуалізованих цілей кожен враховує цілі та інтереси іншого. У таких взаєминах важливим $є$ узгодження поглядів та прагнень між партнерами, а спілкування характеризується повагою і коректністю, умінням поставити себе на місце партнера, зрозуміти його ситуацію та проблеми. 3 точки зору О. Вороніної, партнерська модель гендерних відносин інтегрує інтереси та цінності як чоловіків, так і жінок, враховує існуючі розбіжності між чоловіками та жінками, але не для утворення і збереження ієрархії, а для подолання іiі негативних наслідків[2, с. 13-106 ].

Суб'єктивні і об'єктивні можливості партнерської моделі гендерних відносин виражені в антагональних суперечностях, які існують між чоловіком та жінкою. Вона їх не усуває, а навпаки, передбачає, оскільки існування цього типу суперечностей у відносинах між чоловіками та жінками має об'єктивний характер. Їх неможливо усунути. Вони існуватимуть завжди.

Так, звернення до соціології [1] дає можливість зрозуміти особливість антагональних суперечностей, які вирізняються динамічно-урівноваженим характером, відносною збалансованістю, готовністю сторін до компромісу і конвенцій, а також взаємної відповідальності за зваженість та виконання взятих на себе зобов'язань. В антагональних суперечностях відсутній «чорно-білий» контраст. Вони не передбачають табу на взаємопереходи і взаємоперетворення сторін. Чітке усвідомлення суб'єктами якісних відмінностей між ними не є основою чи причиною антагонізмів. Конкуренти - суперники поважають права і свободи одне одного. Більше того, функціональна асиметрія протилежностей, коли обидві сторони мають тільки 
їм властиві здібності, спонукає до взаємодоповнюваності зусиль у вирішенні завдань, які мають для них взаємовигідно важливе значення.

В антагональних суперечностях кожна із сторін, переймаючись своїми інтересами, водночас змушена виконувати певні зобов'язання і перед власною протилежністю. Керуючись своїми потребами, вона не може не рахуватися з потребами іншої сторони, оскільки ії власне становище i благополуччя в значній мірі залежать від того, як ставитиметься до неї протилежна сторона. Тому суб'єкти беруть на себе зобов'язання не вчиняти дій, в результаті яких їх власне становище покращилося б за рахунок погіршення становища протилежної сторони. У цьому разі, сторони спільними зусиллями забезпечують рівновагу тієї соціальної системи, до якої вони належать.

3 огляду на вищенаведене, в основі дослідження гендерної політики в системі державного управління в рамках гендерної моделі партнерських відносин доцільно керуватися принципом кооперації та принципом рівноправності, які поряд з традиційними принципами паритету, пріоритету та домінантності теж притаманні інтеракції людей кожного соціуму.

Результати, отримані в процесі вивчення та ознайомлення 3 окремими виданнями філософської, соціологічної, історичної літератури 3 теорії кооперації (автори - О. Анциферов, М. Баллін, С. Бородаєвський, Ф. Бюше, I. Витанович, В. Доманицький, Р.Оуен, П. Сорокін, Г. Спенсер, М. ТуганБарановський, Дж. Холіок, О. Чаянов та ін.), є переконливими для висновку, що про кооперацію можна говорити, як про гуртування і співпрацю людей в будь-якій сфері суспільного життя. Це одна із форм організації праці, за якої певна кількість людей бере спільну участь в одному й тому самому або в різних, зв'язаних між собою, виробничих процесах. Принцип кооперації демонструє органічний збіг умов розвитку особистості з фундаментальними імперативами суспільств на певному відрізку історії. Так, К. Маца стверджує, що кооперація - це «...вища форма колективізму, коли між елементами, які входять в систему, точно визначена міра взаємозалежності. При цьому колектив - це завжди в більшій чи меншій мірі, прямо чи опосередковано виражена кооперація елементів, які входять в колектив (систему). I колективність, і кооперативність відображають один і той самий принцип колективістське начало в організації суспільства і виробництва» $[9$, с. 174175]. На думку М. Туган-Барановського, кооперативна взаємодія у будь-якій інституціональній формі - це солідарність примирених інтересів, коли усі однаково зацікавлені, щоб спільна справа мала успіх, що обіцяє численні вигоди окремим учасникам [9]. В «Декларації про кооперативну ідентичність», прийняту на Генеральній Асамблеї Міжнародного Кооперативного Альянсу (1995) виділені такі кооперативні цінності: взаємодопомога, демократія, взаємна відповідальність, справедливість, рівність, чесність, відкритість, солідарність, соціальна відповідальність і турбота про інших [4]. 
Принцип рівноправності громадян в системі гендерно-управлінських відношень (дія цього принципу розкрита, зокрема, в дисертаціях Н.Н.Кукаренко та К.І.Лазар [5; 8 та ін.]) кореспондується 3 принципом універсальності прав людини, який розглядається науковцями як важливий фактор розвитку цивілізації в третьому тисячолітті.

Принцип рівноправності на відміну від принципу паритету забезпечує вихід на рівень іншого діапазону аналізу 3 включенням онтологічних, соціальних і правових основ гендерної рівності, не акцентуючи увагу на відношенні статей та ставить вимогу відповідальності як держави, так і кожного громадянина за створення умов соціального партнерства[14].

Натомість принцип паритету або гендерної паритетності (всебічно проаналізувала i обгрунтувала українська дослідниця О. Кулачек [6-7]) закладає підвалини в модель відносин, коли на передній план випливає питання про пропорційність, квоти і т. п. чоловіків та жінок в системі державного управління. Істотно, якщо ми робимо акценти лише на принципах паритетної демократії то обмежуємося аналізом доктрини національної політики гендерної рівності під кутом зору еволюції (історії) іiі основоположних принципів та ідеології, ідеї рівності у представництві громадян в різних сферах суспільного життя, але «першочергово у політичній сфері. Це природно, позаяк паритетна демократія, згідно із висновками I.О.Грицай, це - система нормативно-впорядкованих та передбачених політико-правовими принципами прав, свобод і обов'язків людини і громадянина, забезпечення можливості їх рівноправного здійснення та дотримання у всіх сферах державно-громадської діяльності за допомогою відповідного механізму реалізації. Вона базується на пропорційному (в ідеалі - паритетному, тобто 50/50) представництві жінок та чоловіків у всіх гілках як законодавчої, так і виконавчої влади» [3].

Висновки. В рамках соціокультурного підходу важливо, щоб в порівняльних характеристиках різних моделей політики гендерної рівності здійснювався аналіз як існуючих моделей типів держав, відносин влади та домінування, так і моделей типів суспільств - антропоцентристського чи соціоцентристського. Такий аналіз дає змогу пояснити не тільки соціальні причини усталених у тому чи іншому суспільстві гендерних стереотипів, а й причини, генетично запрограмовані на рівні ментальних уявлень про роль чоловіка й жінки в суспільстві.

Соціокультурний напрям дослідження спрямований на виявлення особливостей реалізації гендерної політики в системі державного управління України в рамках тієї чи іншої моделі гендеру з урахуванням ментальності як суспільного феномена, глибоко поєднаного сутнісними зв'язками 3 історичними трансформаціями українського суспільства.

Евристичність соціокультурного підходу зростає за умов поєднання його принципів з принципами комплексного та інституційного підходів. Ці підходи взаємодоповнюють один одного, ця єдність дозволяє дослідити 
гендерні відносини у всіх сферах суспільного життя під кутом зору їх системно-структурних характеристик, в генезисі та історичних трансформацій.

\section{Лimepamypa:}

1.Методологія державного управління як галузі науки : [наук. розробка]; авт. кол. : Ю. П. Сурмін, В. Д. Бакуменко, А. О. Краснейчук. - К. : НАДУ, 2010. - 32 с.

2.Скаленко О.Глобальні резерви поступу (інформація + інтелект + інновація) / О. Скаленко. - К.: Основи, 2000. - 394 с.

3.Таворкин Е.П. Информация как научная категория / Е.П.Таворкин. 2006 [Электронный ресурс] - Режим доступа: http. www.i-u. ru/ biblio/archive/tavorkin_ informaciya/

4.Тищик Б. Й. Історія держави і права зарубіжних країн. Новий Час (XVII - 1918 рік) [навч. посіб.] / Б. Й. Тищик. - Львів : Світ, 2013. - 752.

5.Вербець В.В., Субот О.А., Христюк Т.А. Соціологія: Навчальний посібник. - К.: Кондор, 2009. - 550c. - Електрон. аналог друк. вид.: режим доступу: http://westudents.com.ua/glavy/86390-183-problemi-genderno-rvnost-na-suchasnomuetap.html (дата звернення: 01.06.2016) - Назва з екрана.

6.Акімов О. О. Професійна діяльність державних службовців в умовах євроінтеграції України: питання формування психологічної готовності [монографія] / О. О. Акімов. К.: Центр учб. літ., 2014. - 176 с.

7.Лі Жун Інституційна обумовленість трансформації гендерних відносин ( в контексті еволюції культурно-філософської традиції Китаю: дисертація кандидата філософських наук: 09.00.03 [Електронний ресурс] - Режим доступу: http://webcache.googleusercontent.com/search?q=cache:AEVlEnDYYnoJ:irbisnbuv.gov.ua/cgi-bin/irbis_nbuv/cgiirbis_64.exe\%3FC21COM\%3D2\%26I21DBN

8.Говорун Т., Кікінежді О. Стать та сексуальність: Психологічний ракурс / Т.Говорун, О.Кікінеджі. - Тернопіль: Нова книга - Богдан, 1999. - 384 с.

9.Кон I. Бесполый сексизм: Сексуальная культура в России. [Електронний ресурс] Режим доступу: http://sexology.narod.ru/chapt608.html

10.Черняхівська В.В. Влияние гендерных стереотипов на становление женщины как субъекта управленческой деятельности / В.В. Черняхівська // Материалы международной научной конференции «Актуальные проблемы государственного управления» 27/05/2016 Тбилиси С. 93-94.

11.Копієвська О.Р. Гендер у контексті сучасних соціокультурних процесів // О.Р. Гендер //Правові засади формування та розвитку гендерного середовища в Україні [Ю.С.Шемчушенко, Н.М.Оніщенко, Я.М.Шевченко, О.Ф.Андрійко та ін.] ; за заг. ред. Н.М.Оніщенко, Н.М.Пархоменко. - К.: Юридична думка, 2010. - 352 с.

12.Гендерні дослідження : прикладні аспекти [монографія] / [В. П.Кравець, Т.В. Говорун, О. М.Кікінежді та ін.] ; за наук. ред. В. П.Кравця. - Тернопіль : Навчальна книга - Богдан, 2013. - 448 с.

13.Коростылева Н.Н. Гендерное измерение кадровых процессов на государственной гражданской службе / Н.Н.Коростылева // Женщина в российском обществе. - 2014. - № 1.- С. 10-17.

14.Кочкина Е. В., Кириченко М. М., Степанова Н. М. Введение. Дестабилизация политических предписаний полу/ Е. В. Кочкина. // Гендерная реконструкция политических систем: [Сб.]; под ред. Степановой Н. М., Кириченко М. М., Кочкиной Е. В. - СПб.: ИСПГ-Алетея, 2003. - 991 с. - [Електрон. аналог. друк. вид.]:- Режим 
доступу:http://www.owl.ru/win/books/genderpolicy/index.htm (дата звернення: 01.06.2016) Назва з екрана.

\section{References:}

1. Surmin, Yu. P., Bakumenko, V. D., Krasneichuk, A. O. (2010). Metodolohiia derzhavnoho upravlinnia yak haluzi nauky [Methodology of public administration as a branch of science]. Kyiv: NADU [in Ukrainian].

2. Skalenko, O. (2000). Hlobalni rezervy postupu (informatsiia + intelekt + innovatsiia) [Global reserves of progress (information + intelligence + innovation)]. Kyiv: Osnovy [in Ukrainian].

3. Tavokin, E. P. (2006). Informatsiya kak nauchnaya kategoriya [Information as a scientific category]. Retrived from http://ecsocman.hse.ru/data/779/811/1219/001_Tavokin.pdf [in Russian].

4. Tyshchyk, B. Y. (2013). Istoriia derzhavy i prava zarubizhnykh krain. Novyi Chas (KhVII - 1918 rik) [History of the State and Law of Foreign Countries. New Time (XVII 1918)]. Lviv: Svit [in Ukrainian].

5. Verbets, V. V., Subot, O. A., Khrystiuk, T. A. (2009). Sotsiolohiia [Sociology]. Kyiv: Kondor. Retrived from http://westudents.com.ua/glavy/86390-183-problemi-genderno-rvnostna-suchasnomu-etap.html [in Ukrainian].

6. Akimov, O. O. (2014). Profesiina diialnist derzhavnykh sluzhbovtsiv $v$ umovakh yevrointehratsii Ukrainy: pytannia formuvannia psykholohichnoi hotovnosti [Professional activity of civil servants in the conditions of European integration of Ukraine: the issue of psychological readiness formation]. Kyiv: Tsentr uchb. lit. [in Ukrainian].

7. Rong, L. (2010). Instytutsiina obumovlenist transformatsii hendernykh vidnosyn (v konteksti evoliutsii kulturno-filosofskoi tradytsii Kytaiu [Institutional conditionality transformation of gender relations (in the context of the evolution of cultural and philosophical tradition of China)]. Candidate's thesis. Kyiv. Retrived from http://webcache.googleusercontent.com/search?q=cache:AEVlEnDYYnoJ:irbis-nbuv.gov.ua/cgibin/irbis_nbuv/cgiirbis_64.exe\%3FC21COM\%3D2\%26I21DBN [in Ukrainian].

8. Hovorun, T., Kikinezhdi, O. (1999). Stat ta seksualnist: Psykholohichnyi rakurs [Gender and sexuality: Psychological perspective]. Ternopil: Nova knyha - Bohdan [in Ukrainian].

9. Kon, I. (n.d.). Bespolyy seksizm: Seksualnaya kultura v Rossii [Genderless sexism: Sexual culture in Russia]. Retrived from http://sexology.narod.ru/chapt608.html [in Russian].

10. Chernyakhovskaya, V. V. (2016). Vliyanie gendernykh stereotipov na stanovlenie zhenshchiny kak subekta upravlencheskoy deyatelnosti [The influence of gender stereotypes on the formation of women as a subject of managerial activity]. Aktualnye problemy gosudarstvennogo upravleniya - Actual problems of public administration : Materials of the international scientific conference. (pp. 93-94). Tbilisi [in Russian].

11. Kopiievska, O.R., et al. (2010). Hender u konteksti suchasnykh sotsiokulturnykh protsesiv. Pravovi zasady formuvannia ta rozvytku hendernoho seredovyshcha $\mathrm{v}$ Ukraini [Gender in the context of contemporary socio-cultural processes]. N. M. Onishchenko, N. M. Parkhomenko (Eds.). Pravovi zasady formuvannia ta rozvytku hendernoho seredovyshcha $v$ Ukraini - Legal bases of formation and development of gender environment in Ukraine. Kyiv: Yurydychna dumka [in Ukrainian].

12. Kravets, V. P., Hovorun, T.V., Kikinezhdi, O. M. (2013). Genderni doslidzhennia : prykladni aspekty [Gender Studies: Applied Aspects]. V. P.Kravets (Eds.). Ternopil: Navchalna knyha - Bohdan [in Ukrainian]. 
13. Korostyleva, N. N. (2014). Gendernoe izmerenie kadrovykh protsessov na gosudarstvennoy grazhdanskoy sluzhbe [Gender measurement of personnel processes in the state civil service]. Zhenshchina $v$ rossiyskom obshchestve - Woman in Russian society, 1, 10-17 [in Russian].

14. Kochkina, E. V., Kirichenko, M. M., Stepanova, N. M. (2003). Vvedenie. Destabilizatsiya politicheskikh predpisaniy polu [Introduction. Destabilization of political prescriptions for gender]. N. M. Stepanova, M. M. Kirichenko, E. V. Kochkinoy (Eds.). Gendernaya rekonstruktsiya politicheskikh system - Gender reconstruction of political systems. Saint Petersburg: ISPG-Aleteya.

Retrived from http://www.owl.ru/win/books/genderpolicy/index.htm [in Russian] 